\title{
Pathogenesis, Diagnosis, Treatment and Prevention Strategies of Human Coronavirus: A Review
}

\author{
Ayisha Shaukat ${ }^{1}$, Muhammad Saqib Javed ${ }^{2}$
}

${ }^{1}$ Pharmacist, Health Department, Government of Punjab, Lahore, Pakistan; ${ }^{2}$ Instructor Computer Science Department, Virtual University of Pakistan, Lahore, Pakistan

[Received: 17 August 2020; Accepted: 28 September 2020]

\begin{abstract}
Coronaviruses is a group of virus which infects many species of animals, including humans. The rapid outbreak of COVID-19 raised serious attention at national and international levels and it was recognized as a pandemic by the World Health Organization. The disease model comprised of three different phases: replication of virus, hyperactivity of immune system and pulmonary cells destruction. For the diagnosis of asymptomatic carriers, viral nucleic acid (RNA) can be detected by using pharyngeal swab. Isolation of infected persons prevents the transmission and spread risk of the disease. Therapy includes use of oxygen therapy, high-flow nasal cannula (HFNC) and methylprednisolone (IV) and in severe cases adrenaline (IV). Anti-viral drugs such as ritonavir plus lopinavir per-orally and antibiotics (moxifloxacin or any antibiotic) were administered by IM/IV route to prevent secondary bacterial infection. Education campaigns are launched to promote different precautionary measures to avoid disease transmission. [Bangladesh Journal of Infectious Diseases, October 2020;7(suppl_2):S34-S37]
\end{abstract}

Keywords: Covid-19; SARS-CoV-2; Coronavirus; respiratory distress

Correspondence: Ayisha Shaukat, Pharmacist, Health Department, Government of Punjab, Lahore, Pakistan; Email: ayishashaukat@gmail.com; Tel: +923234106446

Conflict of interest: The author has no conflicts of interest to declare.

Funding agency: Authors of this study did not receive funding from any agency.

Contribution to authors: Both authors involved in data collection and literature search up to manuscript writing as well as revision of this manuscript.

How to cite this article: Shaukat A, Javed MS. Pathogenesis, Diagnosis, Treatment and Prevention Strategies of Human Coronavirus: A Review. Bangladesh J Infect Dis 2020;7(suppl_2):S34-S37

Copyright: ( 2020 . Shaukat and Javed. Published by Bangladesh Journal of Infectious Diseases. This article is published under the Creative Commons CC BY-NC License (https://creativecommons.org/licenses/by-nc/4.0/). This license permits use, distribution and reproduction in any medium, provided the original work is properly cited, and is not used for commercial purposes.

\section{Introduction}

Coronaviruses is a group of virus which infects many animal species and humans. The isolation of coronavirus strain from murine (JHM strain), was first reported ${ }^{1-2}$. The name "coronavirus," was derived from "corona" or crown like morphological feature observed under electron microscope ${ }^{3}$. Although common cold and flu is symptom of human coronaviruses. However, in 2003, when it became apparent that a new coronavirus caused severe acute respiratory syndrome (SARS) in humans, coronaviruses became much more recognized. 


\section{Molecular structure of SARS CoV2}

Coronaviruses are positively stranded RNA (approximately $30 \mathrm{~kb}$ ), enveloped viruses with round virion having 80 to $120 \mathrm{~nm}$ diameter ${ }^{4-5}$. The genome RNA of virus is complexed having helical nucleocapsid in viral membrane. Three viral proteins are recognized in the membrane of corona viruses. These are type I glycoprotein spike (S), having peplomers on surface of virion, giving it crown like (corona) morphological feature under electron microscope; membrane protein $(\mathrm{M})$ having a short $\mathrm{N}$-terminal ecto-domain and cytoplasmic tail which spans the membrane thrice; and small highly hydrophobic membrane protein $(\mathrm{E})^{6}$. Zoonotic spillover was due to modifications at spikes level on receptor binding sites. In December 2019, Wuhan city of China became the center of pneumonia epidemic of unknown reason. By January 2020, the novel virus was isolated by Chinese scientists named it as covid-19. This rapid outbreak raised serious attention at national and international levels and within weeks, it was recognized as a pandemic by the World Health Organization, crossing Wuhan and rapidly disseminating in 171 countries worldwide ${ }^{7}$. This poses a significant threat to public health worldwide ${ }^{8-11}$. The epidemic impacted on the China economy as well as different nations across the globe $^{12}$. Several countries including USA, Russia, Europe, Middle East, Arab and Asian countries are prohibiting visitors from China and other countries. Moreover, these countries should take serious measures to educate the public and ensure that person moved from abroad is placed in quarantine for period of two weeks.

\section{Source of SARS CoV2}

COVID-19 produced from SARS-CoV-2 originated from bats as they act as natural host due to its genetic similarities ${ }^{13-16}$. There is alteration in spike glycoprotein of SARS coronavirus-2 indicated by transmission electron, scanning electron and cryoelectron microscopic images. Instead of 2019$\mathrm{nCoV}$, this virus were named by ICTV (International Committee on taxonomy of Viruses) as SARS-CoV-2 as genetic studies showed similarity between SARS coronavirus and COVID19 coronavirus which resulted in severe acute respiratory distress in humans ${ }^{17}$.

\section{SARS-CoV Pathogenesis}

It remained unknown to find the possible mechanism of corona virus infection. However, the disease model comprised of three phases: replication of virus, hyperactivity of immune system and pulmonary cells destruction due to proliferation of epithelial cells, alveolar damage and macrophages infiltration ${ }^{18,19}$. Although COVID-19 is associated with pneumonia, however, the infected patients are also prone to gastrointestinal symptoms such as frequent diarrhea, lymphadenopathy and splenic atrophy ${ }^{20}$. The minimal disruption of intestinal cells while SARS-CoV replication in enterocytes has been attributed to the upregulation of the transforming growth factor and initiation of an antiapoptotic host cellular response in intestinal cells $^{21,22}$. Autopsies studies of virus affected people shown that this infection is basically systemic disease with extrapulmonary dissemination followed by shedding of virus in respiratory secretions, urine, stools and sweat ${ }^{14-15}$.

\section{Diagnosis}

Molecular tools are preferred for early diagnosis of SARS-CoV-2 ${ }^{23-24}$. For asymptomatic carriers' diagnosis, viral RNA detection technique is helpful (detected by using pharyngeal swab). Such persons should be isolated so as to prevent further disease transmission ${ }^{25}$. Real-time RT-PCR (rRT-qPCR) is also one of the technique performed using respiratory secretions to detect viral DNA within short time period ${ }^{26}$. A diagnostic technique reverse transcriptional loop-mediated isothermal amplification (RT-LAMP) was developed by researchers for detection of COVID-19 coronavirus colorimetrically (iLACO technique). In this technique, six primers were used for amplification of fragment of the ORF lab gene, using $\mathrm{pH}$ indicator (phenol red) when amplification occurs, the color turns from pink to light yellow in positive suspects of COVID-19 while in negative cases, it remains pink $^{27}$.

\section{Treatment}

According to the severity of symptoms, patients should be immediately given symptomatic and supportive treatment ${ }^{28-29}$. To reduce breathing stress, therapy consists of high-flow nasal cannula (HFNC) oxygen therapy (supplementary oxygen). To counteract hypoxemia, intravenous infusion of methylprednisolone was given and in severe instance adrenaline was administered intravenously. Anti-viral drugs such as ritonavir plus lopinavir perorally and an antibiotic (moxifloxacin or any antibiotic) was administered by IM/IV route to prevent secondary bacterial infection ${ }^{28,30}$. Numerous drugs are under study such as different antiretrovirals, (remdesevir, oseltamivir) chloroquine and indomethacin. Till the development of vaccine, chinese herbal medicine formula could be an alternative approach for the 
prevention of COVID-19 in high-risk population which require well design population studies to evaluate the preventive effect of Chinese medicine $^{31}$. Design and development of suitable vaccines against this virus is in process and may be time taking ${ }^{32}$. Hence, management of disease by taking precautionary measures in a scientific way is of prime concern by following different guidelines ${ }^{33}$.

\section{Prevention}

Prevention is the only way to overcome this situation by disseminating information through social media across the globe. Education campaigns are launched to promote different precautionary measures including frequent hand washing using soap or use of sanitizers, face mask to inhibit transmission of disease. The community should refrain from crowded places and should remain inside home avoid contacts with animals. Children and elderly have greater susceptibility to disease, hence precautionary measures needs to be taken ${ }^{34}$. Most important thing is to report sign and symptoms like fever, flu, sore throat and cough. Close social contacts to suspected areas and travel history and are also important factors which should not be ignored. The government of every Country should limit the foreign countries tours of travelers so as to limit their exposure to virus affected countries. Quarantine protocols must be followed for people returning back from different virus affected countries ${ }^{35}$.

\section{Conclusion}

Corona (SAR CoVID-19) is a worldwide pandemic. Scientists and various health agencies across the globe are working with efforts to inhibit further spread and transmission and of virus by following strict vigilance, intervention strategies and control policies, and are in a race to fight against virus by designing suitable vaccines and medicines to keep away pandemic situation.

\section{References}

1. Bailey OT, Pappenheimer AM, Sargent F, Cheever MD, Daniels JB. A murine virus (JHM) causing disseminated encephalomyelitis with extensive destruction of myelin. II. Pathology. J Exp Med 1949; 90(3):195-212.

2. Cheever FS, Daniels JB, Pappenheimer AM, Baily OT. A murine virus (JHM) causing disseminated encephalomyelitis with extensive destruction of myelin. I. Isolation and biological properties of the virus. J Exp Med 1949; 90(3):181-94.

3. Almedia JD, Berry DM, Cunningham. CH, Hamre D, Hofstad MS, Malluci L, et al. Coronavirus. Nature. 1968; 220: 650.

4. Lomniczi, BJ. Biological properties of avian coronavirus RNA. J General Virol 1977; 36(3):531-3.
5. Lee HJ, Shieh CK, Gorbalenya AE, Koonin EV, La Monica $\mathrm{N}$, Tuler J, et al. The complete sequence (22 kilobases) of murine coronavirus gene 1 encoding the putative proteases and RNA polymerase. Virology 1991; 180(2):567-82

6. Bond CW, Leibowitz JL, Robb JA. Pathogenic murine coronaviruses. II. Characterization of virus-specific proteins of murine coronaviruses JHMV and A59V. Virology 1979; 94(2): 371-84.

7. World Health Organization. Coronavirus. https://www.who.int/ health-topics/coronavirus. Accessed 6 Mar 2020.

8. Riccucci M. Bats as materia medica: an ethnomedical review and implications for conservation. Vespertilio 2013; 16(16): 249-270.

9. Hu B, Ge X, Wang LF, Shi Z. Bat origin of human coronaviruses. Virol J 2015; 12(1): 221.

10. Li X, Zai J, Zhao Q, Nie Q, Li Y, Foley BT, et al. Evolutionary history, potential intermediate animal host, and crossspecies analyses of SARS-CoV-2. J Med Virol 2020;92(6): 602-11

11. Malik, YS, Sircar S, Bhat S, Sharun K, Dhama K, Dadar M, et al. Emerging novel coronavirus (2019-nCoV)-current scenario, evolutionary perspective based on genome analysis and recent developments. Vet Quart 2020; 40(1): 68-76.

12. Ji W, Wang W, Zhao X, Zai J, Li X. Cross-species transmission of the newly identified coronavirus 2019-nCoV. J Med Virol 2020; 92(4): 433-40.

13. Peiris JS, Guan Y, Yuen KY. Severe acute respiratory syndrome. Nat Med 2004; 10(12): 88-97.

14. Ding Y, He L, Zhang Q, Huang Z, Che X, Hou J, et al. Organ distribution of severe acute respiratory syndrome (SARS) associated coronavirus (SARS-CoV) in SARS patients: implications for pathogenesis and virus transmission pathways. J Pathol 2004; 203(2):622-30.

15. Farcas GA, Poutanen SM, Mazzulli T, Willey BM, Butany $\mathrm{J}$, Asa SL, et al. Fatal severe acute respiratory syndrome is associated with multiorgan involvement by coronavirus. J Infect Dis 2005; 191(2):193-7

16. Deng SQ, Peng HJ. Characteristics of and Public Health Responses to the Coronavirus Disease 2019 Outbreak in China. J Clin Med 2020; 9(2): 575.

17. Ramadan N, Shaib H. Middle East respiratory syndrome coronavirus (MERS-CoV): A review. Germs 2019; 9(1): 35-42. 18. Bond CW, Leibowitz JL, Robb JA. Pathogenic murine coronaviruses. II. Characterization of virus-specific proteins of murine coronaviruses JHMV and A59V. Virology 1979; 94(2):371-84

19. Bonavia A, Zelus BD, Wentworth DE, Talbot PJ, Holmes $\mathrm{KV}$. Identification of a receptor-binding domain of the spike glycoprotein of human coronavirus HCoV-229E. J Virol 2003; 77(4): 2530-8

20. Bosch BJ, de Haan CA, Rottier PJ. Coronavirus spike glycoprotein, extended at the carboxy terminus with green fluorescent protein, is assembly competent. J Virol 2004; 78(14): 7369-78.

21. Bosch BJ, van der Zee R, de Haan CA, Lepault J, Haijema $\mathrm{BJ}$, Versluis $\mathrm{C}$, et al. The coronavirus spike protein is a class I virus fusion protein: structural and functional characterization of the fusion core complex. J Virol 2003; 77(16): 8801-11.

22. Peiris JS, Guan Y, Yuen KY. Severe acute respiratory syndrome. Nat Med. 2004; 10(12): 88-97

23. Zhang W, Zheng XS, Agwanda B, Ommeh S, Zhao K, Lichoti J, et al. Serological evidence of MERS-CoV and HKU8-related CoV co-infection in Kenyan camels. Emerg Microbes Infect 2019; 8(3): 1528-34.

24. Zhang N, Wang L, Deng X. Recent advances in the detection of respiratory virus infection in humans. J Med Virol 2020; 92(4): 408-417.

25. Hu Z, Song C, Xu C, Jin G, Chen Y, Xu X, et al. Clinical characteristics of 24 asymptomatic infections with COVID-19 
screened among close contacts in Nanjing, China. Sci China Life Sci 2020; 63(5): 706-11.

26. Corman VM, Jores J, Meyer B, Younan M, Liljander A, Said MY, et al. Antibodies against MERS coronavirus in dromedary camels, Kenya, 1992-2013. Emerg Infect Dis 2014; 20: 1319-22.

27. Yu L, Wu S, Hao X, Li X, Liu X, Ye S, et al. Rapid colorimetric detection of COVID-19 coronavirus using a reverse tran-scriptional loop-mediated isothermal amplification (RT-LAMP) diagnostic plat-form: iLACO, 2020. https://doi.org/10.1101/2020.02.20.20025874

28. Du B, Qiu HB, Zhan X, Wang YS, Kang HYJ, Li XY, et al. Pharmacotherapeutics for the New Coronavirus Pneumonia. Zhonghua Jie He He Hu Xi Za Zhi 2020; 43: E012

29. Jiang S, Du L, Shi Z. An emerging coronavirus causing pneumonia outbreak in Wuhan, China: calling for developing therapeutic and prophylactic strategies. Emerg Microbes Infect 2020; 9(1): 275-277

30. Xu Z, Shi L, Wang Y, Zhang J, Huang L, Zhang C, et al. Pathological findings of COVID-19 associated with acute respiratory distress syndrome. Lancet Respir Med 2020; 89(4): $420-2$
31. Luo H, Tang QL, Shang YX, Liang SB, Yang M, Robinson $\mathrm{N}$, et al. Can Chinese medicine be used for prevention of corona virus disease 2019 (COVID-19)? A review of historical classics, research evidence and current prevention programs. Chin J Integr Med 2020; 26: 243-250.

32. Dhama K, Karthik K, Khandia R, Chakraborty S, Munjal A, Latheef SK, et al. Advances in Designing and Developing Vaccines, Drugs, and Therapies to Counter Ebola Virus. Front Immunol 2018; 9: 1803.

33. Gao ZC. Efficient management of novel coronavirus pneumonia by efficient prevention and control in scientific manner. Zhonghua Jie He He Hu Xi Za Zhi 2020; 43: E001

34. Shen K, Yang Y, Wang T, Zhao D, Jiang Y, Jin R, et al. Diagnosis, treatment, and prevention of 2019 novel coronavirus infection in children: experts' consensus statement. World J Pediatr 2020; 1-9

35. Cheng VCC, Wong SC, To KKW, Ho PL, Yuen KY. Preparedness and proactive infection control measures against the emerging Wuhan coronavirus pneumonia in China. J Hosp Infect 2020; 104(3): 254-255 